\title{
Herpes simplex virus: isolation, cytopathological characteri- zation and antiviral sensitivity
}

\author{
Carlos Nozawa ${ }^{1}$ \\ Ligia Carla Faccin Galhardi ${ }^{1}$ \\ Wesley Andrade Bomfim ${ }^{1}$ \\ Elbens Marcos Minoreli de Azevedo ${ }^{1}$ \\ Rosa Elisa Carvalho Linhares ${ }^{1}$
}

\author{
Lilian Yumi Hattori ${ }^{1}$ \\ Nayara Lopes ${ }^{1}$ \\ Ligyana Korki de Cândido ${ }^{1}$ \\ Airton dos Santos Gon ${ }^{1}$
}

Abstract: BACKGROUND: Herpes simplex virus (HSV) infection is an endemic disease and it is estimated that 60$95 \%$ of the adult population are infected with symptoms that are usually self-limiting, though they can be serious, extensive and prolonged in immunocompromised individuals, highlighted by the emergence of drug-resistant strains. The study of the wild-type HSV strains based on the cytopathogenic features and its antiviral sensitivity are important in the establishment of an antivirogram for controlling the infection.

OвJECTIVE: This study sought to isolate and examine the cytopathological characteristics of circulating strains of the Herpes simplex virus, from clinical specimens and their sensitivity to commercially available antiherpesvirus drugs, acyclovir, phosphonophormic acid and trifluridine.

MeTHODS: Herpes simplex virus isolation, cytopathological features and antiviral sensitivity assays were performed in cell culture by tissue culture infectious dose or plaque forming unit assay.

RESULTS: From twenty-two clinical specimens, we isolated and adapted nine strains. Overall, the cytopathic effect was detected $24 \mathrm{~h}$ post-infection (p.i.) and the presence of syncytia was remarkable $48 \mathrm{~h}$ p.i., observed after cell staining. Out of eight isolates, four developed plaques of varying sizes. All the isolates were sensitive to acyclovir, phosphonophormic and trifluridine, with the percentage of virus inhibition (\% VI) ranging from $49.7-100 \%$.

CONCLUSIONS: The methodology for HSV isolation and characterization is a straightforward approach, but the drug sensitivity test, regarded as being of great practical importance, needs to be better understood.

Keywords: Antiviral agents; Herpesvirus 1, human; Herpesvirus 2, human

\section{INTRODUCTION}

Herpes simplex virus (HSV) or human herpesvirus (HHV) is a member of the Herpesvirales order, Herpesviridae family, Alphaherpervirinae subfamily, Simplexvirus genus. HSV is an enveloped virus with a genome consisting of a large linear molecule of $152 \mathrm{~kb}$ double-stranded DNA. HSV genes are classified into three groups: immediate early (IE), early (E), and late (L) genes that encode regulatory proteins of replication, replication proteins and structural proteins. The virus establishes latent infection in sensory neurons and ganglia (trigeminal and sacral) for the lifetime of the host. ${ }^{2}$ During latency, there is no expression of viral genes, but some transcripts, known as LAT (Latency-Associated Transcripts) can be detected and found at high levels. There are two serological types, 1 and 2, which mostly cause mucocutaneous infections, resulting in recurrent lesions. ${ }^{3} \mathrm{HSV}-1$ is associated primarily with orofacial infections, whereas HSV-2 is generally associated with anogenital infections, transmitted through sexual contact. ${ }^{4} \mathrm{HSV}$ infection is endemic in all human populations and it is estimated that $60-95 \%$ of the adult population is infec-

Received on 26.02.2013.

Approved by the Advisory Board and accepted for publication on 13.05.2013.

* Work performed at the Departamento de Microbiologia/Centro de Ciências Biológicas, Departamento de Ginecologia e Obstetrícia e Departamento de Clínica Médica/Centro de Ciências da Saúde. Universidade Estadual de Londrina - Londrina (PR), Brasil.

Financial Support: $\mathrm{CNPq}$, Capes and Fundação Araucária

Conflict of Interest: None.

Universidade Estadual de Londrina (UEL) - Londrina (PR), Brasil 
ted by at least one of the species. ${ }^{5}$ The symptoms associated with both virus types are usually self-limiting in healthy individuals, but can be extensive and prolonged in immunocompromised individuals. ${ }^{6}$

In this study, we isolated and studied the cytopathological features of circulating strains of HSV from clinical specimens collected from in- and outpatients with either oral or genital lesions, clinically compatible with herpes simplex infection. Moreover, we analyzed the sensitivity of these isolates against commercially available antiherpesvirus drugs, acyclovir (ACV), phosphonophormic acid (PFA) and trifluridine (F3T).

\section{MATERIAL AND METHODS}

\subsection{Cells and virus}

HEp-2 cell cultures (human larynx epithelial cells carcinoma - ATCC, CCL-23) were grown in Dulbecco's Modified Eagle Medium (DMEM) (*Gibco-BRL, EUA), supplemented with $10 \%$ fetal bovine serum $\left({ }^{*}\right), 100 \mu \mathrm{g} / \mathrm{ml}$ streptomycin $\left({ }^{* *}\right.$ Sigma Chem. Co., EUA), $100 \mathrm{IU} / \mathrm{ml}$ penicillin $\left({ }^{* *}\right)$ and 2.5 $\mu \mathrm{g} / \mathrm{ml}$ amphotericin B (Bristol Myers-Squibb, Brasil). Cell monolayers were used for experiments after a growth period of approximately 48-72 $\mathrm{h}$. Trypsin/versene were used as cell dispersing agents.

Standard HSV-1 supplied by the Departamento de Virologia/IMPG/UFRJ, Rio de Janeiro-RJ, was used as internal control.

\section{Antiherpesvirus drugs}

Acyclovir - ACV (Zynvir, New Farma, Brazil), phosphonophormic acid - PFA (Foscarnet, Hospira, USA) and trifluridine - F3T (Viroptic, Monarch Pharmaceuticals, USA) were used. PFA and F3T were kindly donated by Trade Farma, Brazil).

\section{Clinical specimens}

Clinical specimens were collected between June 2009 and June 2010, of patients aged 12-53, male and female, in- and outpatients of the Hospital Universitario Regional do Norte do Parana - Londrina (HUNRPr/UEL), and a few from university staff and students. Informed consent form was signed by all participants. The project was approved by the UEL Ethics Committee under the registration $n^{\circ} 225 / 09$ PF.

Twenty-two specimens were collected with swabs from skin/mucosa blisters or wounds in areas including the mouth (13), oral cavity wound (1), genitalia (2), perianus (2), conjunctiva (1), leg (1), buttocks (1) and back (1). The specimens were collected in DMEM containing penicillin $(1000 \mathrm{IU} / \mathrm{ml})$, streptomycin $(1000 \mu \mathrm{g} / \mathrm{ml})$ and amphotericin B $(25 \mu \mathrm{g} / \mathrm{ml})$, and kept at $4-8^{\circ} \mathrm{C}$ until laboratory manipulation. The specimens were clarified by centrifugation at 1000 $\mathrm{x} g$ for 10 minutes, in order to remove cell debris.

\section{Cell culture}

Clarified specimens were inoculated into HEp2 cell cultures established in tubes, as previously carried out. ${ }^{7}$ Briefly, $48 \mathrm{~h}$ cell cultures were inoculated with $100 \mu \mathrm{l}$ of the clarified suspension. The cultures were observed for approximately 10 days, in order to monitor for the cytopathic effect (CPE). Up to three blind passages were performed for negative cultures by submitting inoculated cultures to three freezing and thawing cycles, and homogenates were then reinoculated. Negative specimens after three blind passages were discarded. Following serial passages in cells, adapted strains were stored at $-20^{\circ} \mathrm{C}$ with $10 \%$ glycerin.

\section{Hematoxylin-eosin (HE) staining.}

Cell cultures infected with the isolates were subjected to HE staining for better analysis of the CPE. Fifty to sixty percent of confluent HEp-2 cells grown in coverslips were infected with $200 \mu \mathrm{l}$ of the isolates diluted to the tenth. The cultures were monitored for 24-72 $\mathrm{h}$ for the development of CPE. Cultures on coverslips were washed, fixed with phosphate-buffered saline (PBS)/methanol (7 vol:1 vol), (1 vol:1 vol), and finally with undiluted methanol, and stained with HE solution. Coverslips with stained cultures were mounted on slides and observed under a microscope.

\section{Cytotoxic assay of the antivirals}

The cytotoxicity of the commercially available antivirals was determined by MTT kit (dimethylthyazolyl diphenyl tetrazolium bromide) (**) in HEp-2 cells, according to the manufacturer's instructions. HEp-2 cells grown in 96-well microplates (Nunc A/S, Denmark), at $37^{\circ} \mathrm{C}$ under $5 \% \mathrm{CO}_{2}$, in a confluence of $70 \%$, were submitted to the treatment with varying concentrations of the antivirals. The following concentrations were used: $\mathrm{ACV}(0.156,0.312,0.625,1.25,2.5$, $5.0,10 \mathrm{mg} / \mathrm{ml})$, PFA $(0.312,0.625,1.25,2.5,5.0,10$ $\mathrm{mg} / \mathrm{ml})$ and F3T $(0.078,0.156,0.312,0.625,1.25,2.5$ $\mathrm{mg} / \mathrm{ml})$. The percentage of cell viability was calculated as follows, $100-(\mathrm{At} / \mathrm{Ac}) \times 100$, where At and Ac refer to absorbance with the drug and control (untreated cells), respectively. The $50 \%$ cytotoxic concentration $\left(\mathrm{CC}_{50}\right)$ was determined as the concentration of the drugs capable of reducing absorbance by $50 \%$, in comparison with the control by regression analysis.

\section{Plaque reduction assay}

HEp-2 cells grown in 24-well plates (TPP, Switzerland), with $95-100 \%$ confluence, were infected with the isolates and incubated at $37^{\circ} \mathrm{C}$ under $5 \% \mathrm{CO}_{2}$ for $1 \mathrm{~h}$. The cell monolayer was washed and overlaid with nutrient agarose (DMEM [2x] and 1.8\% 
agarose $[\mathrm{v} / \mathrm{v}])$, added to varying concentrations of the antivirals. For PFA, 0.18, 0.375, 0.75, $1.5 \mathrm{mg} / \mathrm{ml}$ were used, and for F3T, the amounts were $0.5,0.25,0.125$ $\mathrm{mg} / \mathrm{ml}$. After $48-72 \mathrm{~h}$ of incubation, the cells were fixed with $10 \%$ formaldehyde in PBS, $\mathrm{pH} 7.3$, for $24 \mathrm{~h}$, and stained with $0.5 \%$ crystal violet. Plaques were counted and the percentage of viral inhibition (\%VI) was calculated as follows, $1-(\mathrm{V} d / \mathrm{V} c) \times 100$, where $\mathrm{V} d$ and $\mathrm{V}_{c}$ refer to the number of plaques in the presence and absence of antivirals, respectively. ${ }^{8}$

Infectious dose reduction assay by tissue culture infectious dose $\left(\mathrm{TCID}_{50}\right)$.

HEp-2 cells grown in 96-well microplates (TPP, Switzerland), with $95-100 \%$ confluence, were infected with the isolates and incubated at $37^{\circ} \mathrm{C}$ under $5 \% \mathrm{CO}_{2}$ for $1 \mathrm{~h}$. Cells were washed and overlaid with medium containing varying concentrations of the antivirals. The amounts for ACV were $0.5,1.5,3,5,10$ $\mathrm{mg} / \mathrm{ml}$; and for PFA, they were $0.1,0.5,1.0,1.5,3.0$ $\mathrm{mg} / \mathrm{ml}$. They were then incubated for 5 days. Appropriate controls were prepared. The viral titer was determined according to standard methods and the percentage of VI was calculated like before. . $^{8,910}$

\section{RESULTS}

The specimens' inoculum presented evidence of CPE. Most revealed a discrete effect at the first passage, but an accentuated effect at subsequent passages. Briefly, infected cells demonstrated cell rounding, increased volume, refringence, and formation of lumps, detected focally in the monolayer, $24-48 \mathrm{~h}$ after inoculation. The presence of syncytia was noticeable after $48 \mathrm{~h}$ of infection (hematoxylin-eosin staining) (Figure 1). Subsequently, at 72-96h p.i., these effects spread throughout the monolayer, and cell detachment from the monolayer was also observed (Figure 2). The CPE was similar to that of standard HSV-1 used as positive control.

The ability of isolates to produce plaques in cell cultures was assessed. Out of nine strains that developed characteristic CPE, only four developed plaques, which had irregular borders of varying sizes (Figure 3). Strains S2 and S4 produced predominantly large plaques with an average diameter of $1.0 \mathrm{~mm}$, while strains 5 and 6 produced predominantly small plaques with an average diameter of $0.4 \mathrm{~mm}$.

Table 1 shows the antiviral sensitivity of four isolates (S2, S4-S6) when tested for fosfonoformic acid (PFA) and trifluridine (F3T).

The sensitivity to antivirals of the isolates that could not be assayed by plaque assay was performed by $\mathrm{TCID}_{50}$ against $\mathrm{ACV}$ and PFA, at the concentrations of $3.0 \mathrm{mg} / \mathrm{ml}$ and $1.5 \mathrm{mg} / \mathrm{ml}$, respectively, as displayed in table 2 .

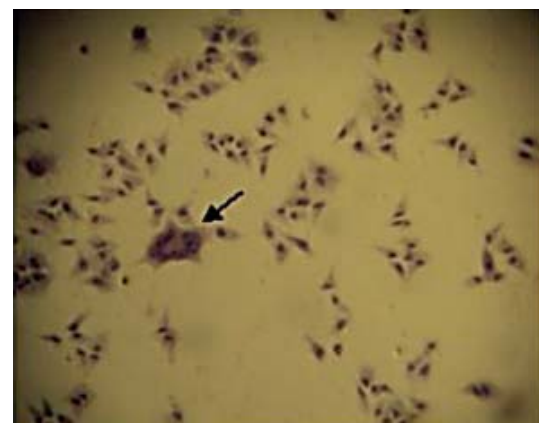

Figure 1: HEp-2 cell cultures infected with the isolate S8. Multinucleate giant cell (syncytium) (arrow) is shown in cultures stained with hematoxylin-eosin $48 \mathrm{~h}$ post-infection $(40 \mathrm{X})$

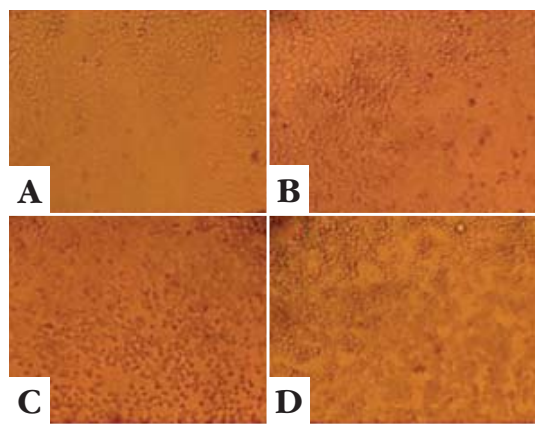

Figure 2: HEp-2 cell cultures infected with the isolate S8. Control noninfected cell cultures (A) and cultures with c y to pat hic effect $48 \mathrm{~h}$ (B), $72 \mathrm{~h}(\mathrm{C})$ and $96 \mathrm{~h}$ (D) post-infection. Unstained fresh cultures (50X))

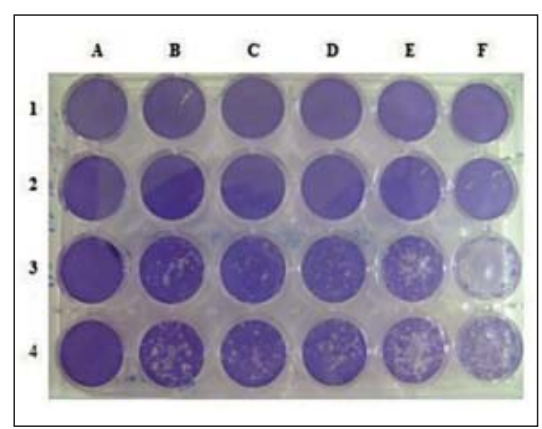

Figure 3:

Plaques developed by isolate S4 (lines 3 and 4 - duplicate) in HEp-2 cell cultures $72 \mathrm{~h}$ postinfection after crystal violet staining (lanes B-F). Non-infected cell control (lines 1 and 2, and lane A)

\section{DISCUSSION}

The study demonstrated the isolation and adaptation of HSV from clinical specimens in cell culture. Further, the cytopathological features of the isolates were assessed, in addition to their sensitivity to some commercially available antiherpesvirus drugs. The development of the CPE was used to monitor the isolation and adaptation of the isolates in fresh preparation or after cell HE staining. HEp-2 cell cultures were used as the cell of choice for their susceptibility. The CPE was observed 24-48h after the inoculation of the clinical specimens, as described 
TABle 1: The sensitivity of the isolates S2, S4-S6 against fosfonoformic acid (PFA) and trifluridine (F3T) by plaque assay

\begin{tabular}{lll}
\hline $\begin{array}{l}\text { VIc } \\
\text { Isolates }\end{array}$ & PFA $^{\mathbf{a}}$ & F3T $^{\mathbf{b}}$ \\
\hline S2 & 90 & 100 \\
S4 & 67 & 100 \\
S5 & 76 & 100 \\
S6 & 85.2 & 100 \\
\hline
\end{tabular}

${ }^{\mathrm{a}}$ Concentration of $1.5 \mathrm{mg} / \mathrm{ml}$; ${ }^{\text {b }}$ Concentration of $0.5 \mathrm{mg} / \mathrm{ml}$;

'Viral inhibition (\%)

TABLE 2: The sensitivity of the isolates S7-S11 for acyclovir (ACV) and fosfonoformic acid (PFA) by TCID50 assay

\begin{tabular}{lll}
\hline $\begin{array}{l}\text { VIc } \\
\text { Isolates }\end{array}$ & ACV & PFA $^{\mathbf{b}}$ \\
\hline S7 & 99.9 & 99.9 \\
S8 & 94.9 & 94.9 \\
S9 & 90.0 & 90.0 \\
S10 & 96.8 & 96.8 \\
S11 & 85.0 & 90.0 \\
\hline
\end{tabular}

${ }^{\mathrm{a}}$ Concentration of $1.5 \mathrm{mg} / \mathrm{ml}$; ${ }^{\mathrm{b}}$ Concentration of $0.5 \mathrm{mg} / \mathrm{ml}$;

c Viral inhibition (\%)

above. ${ }^{12,13}$ Infected cells presented increased cytoplasm refringence, cell rounding and clumping, initially in a focal pattern. Later, this effect was disseminated throughout the cell monolayer, in accordance with previous results. ${ }^{14}$ Characteristically, giant multinucleated cells were observed after HE staining of infected cells, as previously shown in epithelial keratinocytes. ${ }^{15}$ The isolation of HSV in cell culture as a diagnostic method for HSV infection has been recognized for its efficiency, rapidity and low cost, as has been demonstrated elsewhere. However, it has been shown that less than $60 \%$ of HSV infections are detected. Moreover, the varicella zoster virus can also be isolated easily in cell culture, with similar cytopathological features. Thus, confirmation with immunocytochemistry or molecular assays is necessary.
After the cell culture isolation and adaptation, the ability of isolates to produce plaques as an additional cytopathological feature, was studied. We found isolates that developed small plaques and other, predominately large plaques that could represent mutants of plaque-size. Genetically stable virus populations are expected to produce uniform-sized plaques. Uniform-sized HSV plaques, with well-defined contours and diameters of approximately $1.2 \mathrm{~mm}$, were detected elsewhere. ${ }^{22}$ Furthermore, HSV plaque size has been used to distinguish HSV-1 from HSV-2. ${ }^{23,24}$ In those isolates that produced plaques of varying sizes, there was a prevalence of large plaques, suggesting the occurrence of mutants. It was shown that HSV wild and mutant strains produced plaques with diameters of 0.7-1.2 $\mathrm{mm}$ and 1.4-2.4 mm, respectively, and it was suggested that large plaque mutants be selected after several passages in cell cultures. ${ }^{25,26}$ Concerning the sensitivity of the isolates to commercially available antiherpesvirus drugs, we demonstrated that ACV, PFA and F3T inhibited the isolates to varying degrees, from $49.7-100 \%$, based on the percentage of viral inhibition. The study of HSV sensitivity antiviral drugs is a valuable tool for evaluating HSV infections, particularly in immunocompromised patients, with respect to the emergence of ACV-resistant mutants. ${ }^{27}$ Yet today, there is no consensus between in vitro drug susceptibility and drug resistance in vivo for a given virus infection. ${ }^{28}$ However, clinical studies have demonstrated a significant correlation of in vitro results with the corresponding treatment response. ${ }^{29}$ It has been shown that both assays based on plaque reduction and infectious dose reduction are leading methods for evaluating drug sensitivity. ${ }^{30,31}$ The importance of in vitro evaluation of virus sensitivity to drugs is highlighted in understanding the mechanisms of resistant emergence, drug concentration and the limit of susceptibility and resistance, amongst other factors.

\section{CONCLUSION}

In conclusion, we suggest that the methodology for HSV isolation and characterization is a straightforward approach, though the drug sensitivity test, considered to be of great practical importance, needs to be better understood. 


\section{REFERENCES}

1. Kuo YC, Lee YC, Leu YL, Tsai WJ, Chang SC. Efficacy of orally administered Lobelia chinensis extracts on herpes simplex virus type 1 infection in BALB/c mice. Antiviral Res. 2008;80:206-12.

2. Griffiths PD. Herpesviruses. Medicine 2009;37:668-72.

3. Roizman B, Knipe DM, Whitley RJ. Herpes Simplex Virus. In: Knipe DM, Howley PM, editors. Fields Virology. Philadelphia: Lippincott Williams \& Wilkins; 2007. p. 2502-601.

4. Yeung-Yue KA, Brentjens MH, Lee PC, Tyring SK. Herpes simplex viruses 1 and 2. Dermatol Clin. 2002;20:249-66.

5. Brady RC, Bernstein DI. Treatment of herpes simplex virus infections. Antiviral Res. 2004;61:73-81.

6. Lupi 0. Herpes simplex. An Bras Dermatol. 2000;75:261-75.

7. Ramos AP, Stefanelli CC, Linhares RE, de Brito BG, Santos N, Gouvea V, et al. The stability of porcine rotavirus in feces. Vet Microbiol. 2000;71:1-8.

8. Nishimura T, Toku H, Fukuyasu H. Antivirals compounds. XII. Antiviral activity of amidinohydrazones of alkoxyphenyl-substituted carbonyl compounds against influenza virus in eggs and in mice. Kitasato Arch Exp Med. 1977;50:39-46.

9. Reed LJ, Müench H. A simple method of estimating fifty percent endpoints. Am J Hyg. 1938;27:493-7.

10. Rovozzo GC, Burke CN. A Manual of Basic Virological Tecniques. New Jersey: Prentice Hall Inc; 1973. p. 64-93.

11. Walpita $\mathrm{P}$, Darougar $\mathrm{S}$, Thaker U. A rapid and sensitive culture test for detecting herpes simplex virus from the eye. Br J Ophthalmol. 1985;69:637-9.

12. Whitley RJ, Roizman B. Herpes simplex virus infections. Lancet. 2001;357:1513-8.

13. Scoular A. Using the evidence base on genital herpes: optimising the use of diagnostic tests and information provision. Sex Transm Infect. 2002;78:160-5.

14. Athmanathan S, Reddy SB, Nutheti R, Rao GN. Comparison of an immortalized human corneal epithelial cell line with Vero cells in the isolation of herpes simplex virus-1 for the laboratory diagnosis of herpes simplex keratitis. BMC Ophthalmol. 2002;2:3.

15. Syrjänen S, Mikola $H$, Nykänen $M$, Hukkanen V. In vitro establishment of lytic and nonproductive infection by herpes simplex virus type 1 in three-dimensional keratinocyte culture. J Virol. 1996;70:6524-8.

16. Oranje AP, Folkers E. The Tzanck smear: old, but still of inestimable value. Pediatr Dermatol. 1988:5:127-9.

17. Solomon AR. New diagnostic tests for herpes simplex and varicella zoster infections. J Am Acad Dermatol. 1988;18:218-21.

18. Greenberg MS. Herpesvirus infections. Dent Clin North Am. 1996;40:359-68

19. Greenberg MS. Ulcerative, vesicular, and bullous lesions. In: Greenberg MS, Glick M, editors. Burket's Oral Medicine: Diagnosis and Treatment. Ontario: BC Decker; 2003. p. 50-84.

20. Huber MA. Herpes simplex type-1 virus infection. Quintessence Int. 2003;34:453-67.

21. Arduino PG, Porter SR. Herpes simplex virus type 1 infection: overview on relevant clinico-pathological features. J Oral Pathol Med. 2008;37:107-21.
22. Leary JJ, Wittrock R, Sarisky RT, Weinberg A, Levin MJ. Susceptibilities of herpes simplex viruses to penciclovir and acyclovir in eight cell lines. Antimicrob Agents Chemother. 2002;46:762-8.

23. Lowry SP, Melnick JL, Rawls WE. Investigation of plaque formation in chick embryo cells as a biological marker for distinguishing herpes virus type 2 from type $1 \mathrm{~J} \mathrm{Gen}$ Virol. 1971;10:1-9.

24. Plummer G, Goodheart CR, Miyagi M, Skinner GR, Thouless ME, Wildy P. Herpes Simplex Viruses: Discrimination of types and correlation between different characteristics. Virology. 1974;60:206-16.

25. Plummer G, Waner JL, Phuangsab A, Goodheart CR. Type 1 and type 2 herpes simplex viruses: serological and biological differences. J Virol. 1970;5:51-9.

26. Yamamoto S, Kabuta H, Nakagawa Y. Mutants of Herpes simplex virus. I. Isolation and properties of mutants characterized by plaque size and cytopathogenicity. Kurume Med J. 1972;19:23-31.

27. Cotarelo M, Catalán P, Sánchez-Carrillo C, Menasalvas A, Cercenado E, Tenorio A, et al. Cytopathic effect inhibition assay for determining the in vitro susceptibility of herpes simplex virus to antiviral agents. J Antimicrob Chemother. 1999;44:705-8.

28. Rabella N, Otegui M, Labeaga R, Rodríguez P, Margall N, Gurguí M, et al. Antiviral susceptibility of Herpes simplex viruses and its clinical correlates: a single center's experience. Clin Infect Dis. 2002;34:1055-60.

29. Safrin S, Palacios E, Leahy BJ. Comparative Evaluation of Microplate Enzyme-Linked Immunosorbent Assay versus Plaque Reduction Assay for Antiviral Susceptibility Testing of Herpes Simplex Virus Isolates. Antimicrob Agents Chemother. 1996:40:1017-9.

30. de la Iglesia P, Melón S, López B, Rodriguez M, Blanco MI, Mellado P, et al. Rapid screening tests for determining in vitro susceptibility of herpes simplex virus clinical isolates. J Clin Microbiol. 1998;36:2389-91.

31. Hodinka R, Swierkosz E, Lancaster D, Moore BM, Sacks S, Scholl D, et al. Antiviral susceptibility testing. Proposed standard M33-P. National Committee for Clinical Laboratory Standards: Wayne, PA; 2000.

MAILING ADDRESS:
Prof. Carlos Nozawa
Departamento de Microbiologia/CCB/UEL
Rod. Celso Garcia Cid, km 380
86057-970 - Londrina - PR
Brazil
E-mail:cnoz@uel.br

How to cite this article: Nozawa C, Hattori LY, Galhardi LCF, Lopes N, Bomfim WA, de Cândido LK, Azevedo EMM, Gon AS, Linhares REC. Herpes simplex virus: isolation, cytopathological characterization and antiviral sensitivity. An Bras Dermatol. 2014;89(3):448-52. 